
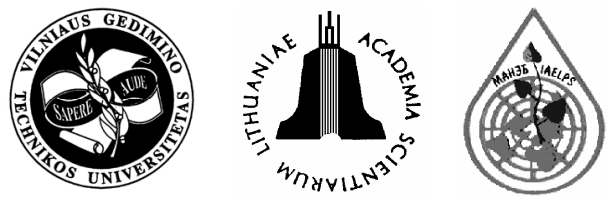

\title{
INVESTIGATION INTO DETERMINING THE HUMIDITY OF CHARGE USED FOR BIOLOGICAL AIR TREATMENT
}

\author{
Pranas Baltrėnas ${ }^{1}$, Alvydas Zagorskis ${ }^{2}$ \\ Dept of Environmental Protection, Vilnius Gediminas Technical University, \\ Saulètekio al. 11, LT-10223 Vilnius, Lithuania \\ E-mail:1pbalt@ap.vgtu.lt; ${ }^{1} a l v y d a s @ a p . v g t u . l t ~$
}

Submitted 7 Sept. 2007; accepted 8 Oct. 2007

\begin{abstract}
Microorganisms can reproduce only in such substrata which contain a certain amount of water and dissolved nutritious substances. Therefore, it is necessary to search for such charges that are distinguished by a large filtering surface and good humidity-retaining properties. In experiments three types of materials - wood, zeolite and foam - were used as a charge for the biological air-cleaning process. The charges were mixed up to maintain humidity necessary for the microorganisms in the biofilter as long as possible. The charges were placed into three different cassettes in the biofilter. The wood charge consisted of wood chips of 10-15 mm and that of zeolite contained 10-12 $\mathrm{mm}$ of zeolite granules. The foam rubber was cut into separate cubes each having the dimensions of $30 \times 30 \times 20 \mathrm{~mm}$. Dependence of the charge humidity on the airflow rate, temperature, time and charge thickness was determined in the work. During the experiments the airflow rate reached $0.1-0.6 \mathrm{~m} / \mathrm{sec}$., and the temperature ranged from 15 to $35^{\circ} \mathrm{C}$. Foam showed the best sorption properties, but a better distribution of humidity was found in the wood-chip charge.
\end{abstract}

Keywords: biofilter, volatile organic compounds, biodegradation, zeolite, adsorption, microorganisms.

\section{Introduction}

Presently, the method of biological air treatment is widely applied for cleaning up air from volatile organic compounds on the global scale $[1,2]$. The method is based on the destruction of organic compounds performed by microorganisms. Many microorganisms are capable of using the components of organic compounds as sources of energy and carbon. Microorganisms can reproduce only in such substrata that contain a certain amount of water and dissolved nutritious substances [3, 4]. Water is the most important medium where metabolism of organisms takes place. All chemical reactions occurring in live organisms need water. Water accounts for $75 \%$ and more of the microorganisms' biomass [5]. Consequently, the efficiency of air cleaning depends on the humidity of a charge which has to be neither too humid nor too dry [6]. A laboratory air-treatment equipment, a biofilter, filled with the charge of different origins composed of wood chips, zeolite and foam rubber, was used for experimental investigation. These materials were mixed up in order to maintain the level of charge humidity necessary for microorganisms.

To have a normal biological treatment process, the optimum conditions of temperature, humidity and aeration as well as the optimum of $\mathrm{pH}$ and the content of $\mathrm{N}, \mathrm{P}$, $\mathrm{K}$ and trace elements in soil have to be maintained. This ensures intensive reproduction of OOM (oil-oxidising microorganisms), whose basis is formed of Pseudomonas fluorescens, Bacillus cereus, Penicillium decumbens Thom,
Serratia, Acinetobacter, Trichoderma and others, and the optimum degradation of oil products [7].

To maintain better development of microorganisms, the charge has to be moistened. Prior to launching the biofilter, the biomedium has to be humidified, i.e. the humidity of $70-85 \%$ has to be maintained in the biomedium. Charge humidity means the mass that is lost when drying the charge according to the methods given below. Moisture is expressed in percent of the original sample mass.

The medium has to contain water, but its excess is not allowed. Water is a substance that is most widely spread in the biosphere. It is distinguished by unique properties. It easily reacts with alkaline metals and volatile organic compounds by forming hydroxides.

Microorganisms need humidity for the transfer of biogenic elements $(\mathrm{K}, \mathrm{N}, \mathrm{P})$, metabolism processes and maintenance of the cell structure. Excess humidity is not desirable because:

1) when water occupies a large part of charge pores, air permeability and aeration efficiency decrease, but the cleaning efficiency rises;

2) 2) excess humidity reinforces washing of pollutants and biogenic elements out of the charge [7].

The optimal charge moisture is 70-85\%.

During the cleaning process the amount of humidity changes. When moving through the charge, vapoursaturated air removes humidity in this way reducing the charge humidity. But simultaneously, a biodegradation process transforms organic compounds into carbon dioxide 
$\left(\mathrm{CO}_{2}\right)$ and water, partially restoring the content of humidity. During decomposition of $1 \mathrm{~kg}$ of hydrocarbon, $1.5 \mathrm{~kg}$ of water is generated. This amount of water is often insufficient, and therefore the charge has to be watered additionally [8].

To obtain a new knowledge of biocharges, first of all, the sorption properties of charges, composed of wood chips, zeolite and foam used for air purification, have to be determined.

\section{Investigation methods}

The experiments were carried out using a biological air-treatment equipment - a biofilter. Even though the biofilter contains five cassettes, with the aim to ensure a uniform airflow rate before the charge for all charges, only one, middle, cassette was used for experiments (Fig 1). The charge is the main element of the biofilter [9]. In experiments three types of materials - wood, zeolite and foam - were used. Charges of different fractions considering their physical properties, such as density, porosity, mass, surface area, and aerodynamic resistance, were selected for the experiment [10]. The wood charge consisted of wood-chip granules of $10-15 \mathrm{~mm}$ fractions, and that of zeolite $-10-12 \mathrm{~mm}$ fractions. Foam was cut into separate cubes each having the dimensions of $30 \times 30 \times 20 \mathrm{~mm}$ (Fig 2). Seeking to maintain humidity necessary for the microorganisms in the biofilter as long as possible, the experiments were performed with intermixed charges of a different origin. Wood chips were mixed with zeolite at the ratio of (according to the volume) 50:50, and with pieces of form at the ratio of $50: 50$.

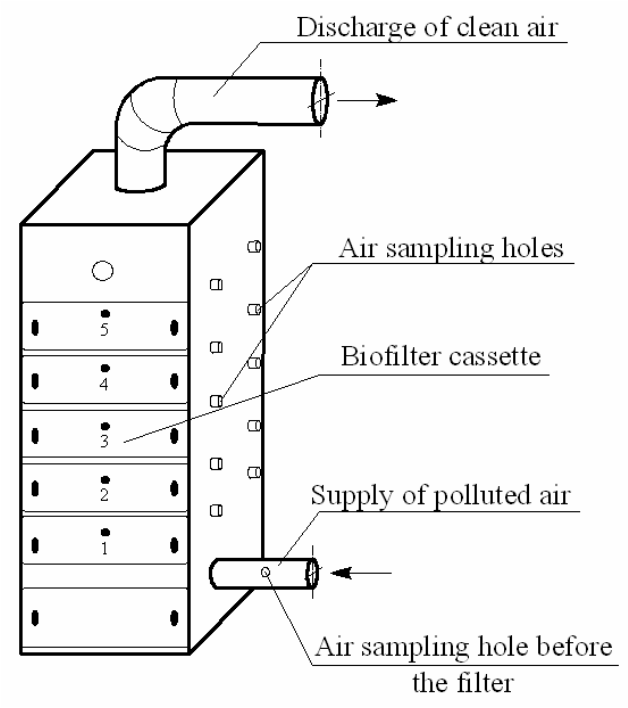

Fig 1. Stand of the laboratory biofilter

Initially, experiments were performed with wood chips. The chips were placed into the biofilter cassette of the following dimensions: $500 \times 450 \times 150 \mathrm{~mm}$. The height of the chip layer in the cassette reached $100 \mathrm{~mm}$. Seeking to ensure the tightness of the charge layer as well as an even distribution of humidity within the entire surface, from the top the charge was covered with a rigid sieve whose pore diameter was $2 \mathrm{~mm}$. Since microorganisms, transforming volatile compounds into carbon dioxide and water have a major impact on the charge humidity, conditions favourable for the reproduction of microorganisms were maintained in the biofilter [10].

Therefore, the air temperature of $30{ }^{\circ} \mathrm{C}$ was maintained with the help of heat exchangers fitted to the biofilter's sides. After filling the cassette with wood chips, 11 of water saturated with mineral salts was sprayed over the charge with the help of nozzles fitted above the charge layer. With the help of small pumps, water was supplied to the nozzles from a reservoir installed at the bottom of the biofilter. After spraying 11 of water with a ventilator switched off, 20 minutes were allowed for water to settle and soak into the charge. Excess water returned to the water reservoir via a metal mesh installed at the bottom of the cassette [11].

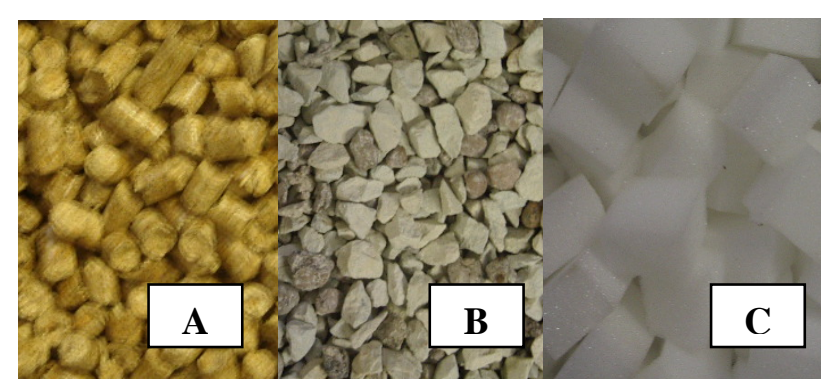

Fig 2. Biocharge of the biofilter: A - wood in chips, $\mathrm{B}-$ Zeovit sirment, $\mathrm{C}$ - foam rubber

After 20 minutes, airflow was supplied to the equipment via a ventilator, installed in an air-feeding tube, at the rate of $0.1 \mathrm{~m} / \mathrm{sec}$. The air-feeding tube has an airflow control valve that enables the change of airflow rate from 0.1 to $0.6 \mathrm{~m} / \mathrm{sec}$. Airflow rate was measured with the airflow rate meter TESTO 400, and the duration of air feeding reached 3 hours. In order to thoroughly evaluate the charge humidity retention properties, samples for humidity setting were taken at different points and depths of the charge layer (Fig 3).

The humidity of charges was determined by a weighted method. This method is distinguished by the fact that it allows the reduction of oxidation, degradation or any other loss of other volatile substances at the same time ensuring higher efficiency of humidity removal from the sample being dried.
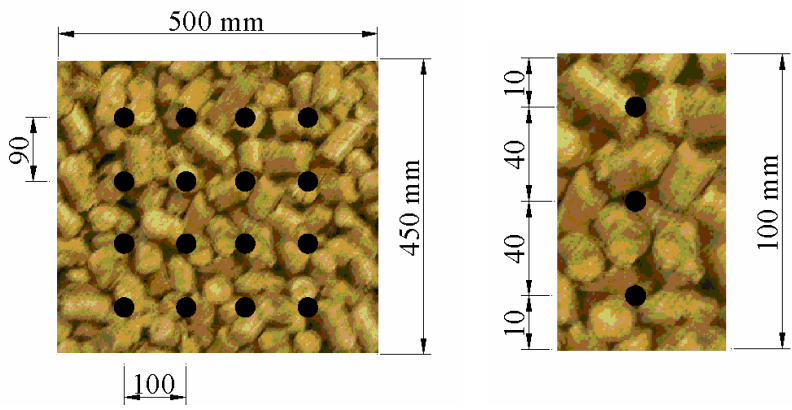

Fig 3. Sampling points 
Prior to sampling, weighing bottles with a cover having the same number were kept in a drying oven at the temperature of $105{ }^{\circ} \mathrm{C}$ for one hour, afterwards they were cooled in a desiccator. Weighing bottles made of glass (approximately $0.5 \mathrm{~mm}$ thick), having hermetic caps to protect them from humidity increase or decrease, a flat bottom and even sides, were used for the experiments. The dried weighing bottles with their caps on were weighed with an analytical balance by recording the readings in the data register. The accuracy of $0.001 \mathrm{~g}$ was used during weighing.

Samples of $1 \mathrm{~g}$ were placed into the weighing bottles which were corked up. A work sample was evenly spread on the weighing bottle's bottom $\left(0.2 \mathrm{~g} / \mathrm{cm}^{2}\right)$. An empty weighing bottle with a cap was weighed before and after its filling with the charge. Afterward the weighing bottle was quickly placed into the drying oven on a cover and was dried for 3 hours by maintaining the temperature of $105 \pm 2{ }^{\circ} \mathrm{C}$.

Wood chips were dried at a regular high temperature. The calculation of the drying time was started when the required temperature was reached within the drying oven. A well-insulated electric drying oven with a thermal regulator and capable of maintaining a sufficiently regular temperature within the oven and the set temperature of a shelf, where samples are dried, were used during experiments. The temperature inside the oven was maintained at the accuracy of $0.5^{\circ} \mathrm{C}$ [12].

At the end of the drying time, the weighing bottle was covered and placed into a desiccator to be cooled for 45 minutes. After cooling the weighing bottle with all its contents and cap was weighed. When determining the humidity of samples, the relative humidity of the laboratory air was around $60 \%$.

The cooled weighing bottles were weighed, and the content of humidity, as a percent expression of the sample mass, was calculated to one digit after a comma and set according to the formula [12]:

$$
M_{\text {charge } e}=\frac{\left(m_{2}-m_{3}\right)}{\left(m_{2}-m_{1}\right)} \cdot 100,
$$

where $m_{1}$ - mass of weighing bottle with a cap, in grams; $m_{2}$ - mass of weighing bottle with a cap and charge sample before drying, in grams; $m_{3}$ - mass of weighing bottle with a cap and charge sample after drying, in grams.

The obtained result of the analysis is the arithmetical mean of humidity amount of three samples when difference between them does not exceed $0.2 \%$. Otherwise, the humidity of samples is determined once again.

When the supplied airflow rate was increased to $0.2 \mathrm{~m} / \mathrm{sec}$., the study to determine charge humidity was repeated. In this way the dependence of wood chips on the fed airflow rate was determined by gradually increasing the rate to $0.5 \mathrm{~m} / \mathrm{sec}$.

An analogous experiment was made with natural zeolite and foam. To preserve the humidity necessary for the microorganisms in the biofilter as long as possible, wood chips were mixed with zeolite and foam during the experiment.

Lower temperatures are recommended for drying foam because it loses fire-proof properties at a lower tempe- rature compared to wood and zeolite. To prevent the change of foam properties, weighing bottles with foam rubber were dried at the temperature of $70^{\circ} \mathrm{C}$.

Seeking to avoid a high aerodynamic resistance of the charge and great air impacts, the layer of the filtering charge was not thick. The layer of charges consisting of zeolite granules and foam reached $100 \mathrm{~mm}$.

To determine the dependence of charge humidity on time, the supplied airflow rate in the biofilter reached $0.2 \mathrm{~m} / \mathrm{sec}$., and temperature $-30{ }^{\circ} \mathrm{C}$. Samples were taken prior to setting the biofilter for operation, and afterwards every two hours by preserving regular rate and temperature in the biofilter. The time interval of the experiment ranged from 0 to 24 hours.

To determine the dependence of charge humidity on the biomedium temperature, the temperatures of 15,20 , $25,30,35^{\circ} \mathrm{C}$ were maintained in the biofilter. The temperature in the equipment can be regulated with a preinstalled temperature sensor. During the experiment, airflow was fed to the device at the rate of $0.2 \mathrm{~m} / \mathrm{sec}$. for 5 hours. After taking samples and obtaining study results, the dependence of charge humidity on temperature curve was derived.

\section{Experimental results}

The humidity of a charge depends on the sorption properties of a substance. The experiments show that foam has the best properties of water sorption.

11 of water was supplied to a cassette, $0.45 \times 0.50 \times$ $0.15 \mathrm{~m}$, filled with pieces of foam. In the initial phase, when air was blown through the charge at the rate of $0.1 \mathrm{~m} / \mathrm{sec}$., the foam humidity after three hours changed insignificantly and reached around $75 \%$. After increasing the airflow rate to $0.5 \mathrm{~m} / \mathrm{sec}$., charge humidity decreased to $70 \%$. In order to improve the sorption properties of the charge, foam was mixed with wood sawdust. The microorganisms present in wood sawdust can develop in a synthetic charge, such as foam, because foam is distinguished by very good oleophylic and hydrophobic properties. As determined by the experiment, when air is fed to the biofilter at the rate of $0.1 \mathrm{~m} / \mathrm{sec}$., the humidity of the charge consisting of wood and foam reaches $73 \%$. When the airflow rate is increased to $0.5 \mathrm{~m} / \mathrm{sec}$., the charge humidity falls by $6 \%$. But the charge consisting of wood and foam has several shortcomings. When the humidity of the charge is high, its aerodynamic resistance increases. In addition, the useful life of foam also decreases. Foam is not resistant to aggressive environmental factors impacting on it during the biofilter operation, such as humidity, temperature, various chemical compounds. As the results given in Fig 4 show, wood humidity is similar to that of foam and changes from $75 \%$ to $66 \%$. The humidity of wood, through which airflow is supplied at the rate of $0.1 \mathrm{~m} / \mathrm{sec}$, , reaches around $75 \%$. When the airflow rate increases to $0.5 \mathrm{~m} / \mathrm{sec}$., the humidity content in the charge drops to $65 \%$. Zeolite had the lowest sorption properties.

After pouring 11 of water on the charge, its humidity reached $18 \%$. A low degree of humidity was predetermined by a small porosity of the charge. To improve it, the charge fraction has to be reduced from $10-12 \mathrm{~mm}$ to $3-5 \mathrm{~mm}$. 


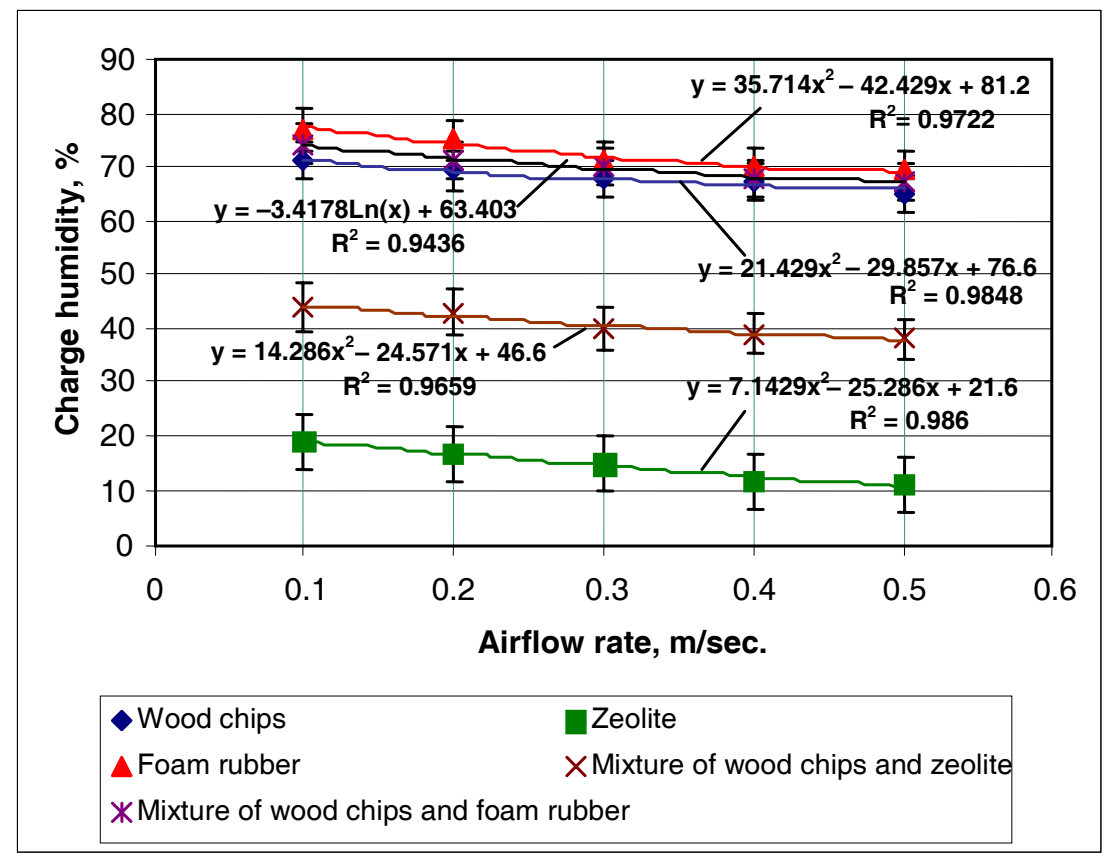

Fig 4. Dependence of the charge humidity on the airflow rate

To extend the useful life of the charge the recommendation is to use a charge made of wood chips and zeolite. Wood porosity, i.e. the ratio of pores-meshes and hollow volume to the total volume of the substance, has an influence on the humidity of wood chips. Wood chips have a communicating porous structure which increases water absorption. Wood chips increase the charge humidity up to $45 \%$. In the meantime zeolite is distinguished by a bigger amount of closed pores which increases the useful life and the surface area of the charge and at the same time the number of microorganisms in the charge. During experiments it was determined that, when increasing the supplied airflow rate, the humidity of the charge consisting of wood chips and zeolite decreased slower compared to other charges. Upon increasing the airflow rate from 0.4 to $0.5 \mathrm{~m} / \mathrm{sec}$. the loss of humidity increased hardly by $1 \%$. The mixture of zeolite and wood chips increases the amount of oxygen in the charge. Oxygen, as one of vital factors of metabolism, is necessary for vital activities of microorganisms decomposing organic compounds. Therefore, upon increasing the amount of oxygen in the charge, the number of microorganisms, evolving water that accumulates during decomposition of organic compounds, also increases. In this way, water input in the biofilter is reduced.

The rate and degree of water adsorption by substances depend on environmental humidity and the duration of staying in a humid environment. The results given in Fig 5 show that the charge humidity changes evenly when air is fed at the rate of $0.2 \mathrm{~m} / \mathrm{sec}$. However, the least loss of humidity is sustained by foam. The experimental results show that after 18 hours of air feeding the amount of humidity in foam decreases to $65 \%$, and after another 6 hours - to $63 \%$. The amount of humidity in the charge for the most part depends on its coefficient of porosity. The charge consisting of wood chips and foam has a ra- ther even decrease of humidity. Both wood and foam, consisting of polymeric substances, have good water sorption properties. Even after 24 hours at the humidity of $59 \%$ microorganisms can develop well because the charge of the said humidity contains a sufficient amount of nutritious substances. A charge composed of wood and foam is a sufficiently good biomedium for the development of microorganisms; however, in the course of time the properties of charge change and, therefore, it has to be changed more often.

The biggest humidity loss is incurred by wood. In 24 hours its humidity decreases from $73 \%$ to $53 \%$. Wood application for biological air treatment is prospective. If the charge has a low humidity, it can work efficiently. Wood humidity with regard to time changes rather evenly, and this facilitates the control of humidity in the charge because the microorganisms receive energy not only from salts dissolved in water but also from carbon contained in wood. Apart from that, wood is easily obtained from nature and forms waste in some branches of industry.

To extend the charge's useful life, zeolite can be mixed with wood chips. Due to its physical and chemical properties zeolite has sufficient resistance to an aggressive environment that is necessary to maintain microorganisms' energy in the biofilter. Apart from that, zeolite is sufficiently to mechanical factors, therefore, even after several years the structure of its surface does not change, and this has a major impact on the transfer of oxygen in the charge. Due to its internal structure, zeolite shows good sorption properties, therefore, even upon a significant decrease of the concentration of supplied organic compounds, it can serve as an adsorbent.

The recommendation is to use this charge mixed with wood chips containing carbon in order that microorganisms could receive nutritious substances if the feeding 
of organic compounds is disturbed. As the experimental results show, the humidity of charge consisting of zeolite and wood chips after 4 hours decreased from 45 to $40 \%$. Later it changed insignificantly, and after 24 hours reached $36 \%$. Such a low humidity of the charge was predetermined by a considerably high density of zeolite. In order to increase the charge humidity, the zeolite fraction has to be reduced to $3-5 \mathrm{~mm}$.

During the initial stage of experiments, a rather big loss of humidity was received. As the experiments show, the zeolite humidity after 24 hours decreased from 17 to $9 \%$. This happens due to the fact that free humidity evaporates first of all, i.e. water evaporates faster from a zeolite surface. Taking into consideration the fact that the porosity of zeolite is not high, a part of humidity accumulated in cell walls and remaining inside its internal part evaporates slower. Microorganisms can develop quicker in the upper part of a zeolite surface. However, both bacteria and micromycetes may be easily affected because it is difficult to maintain a uniform humidity of a zeolite surface. Since a zeolite surface is rather soft, it is more difficult for microorganisms to adhere to it and, apart from that, humidity evaporates rather quickly from the surface of zeolite. Therefore, the use of single zeolite for biological air treatment is not recommended. To improve the humidity of zeolite, its fraction has to be reduced.

One of the main factors predetermining changes in the charge humidity is the temperature of fed air (Fig 6).

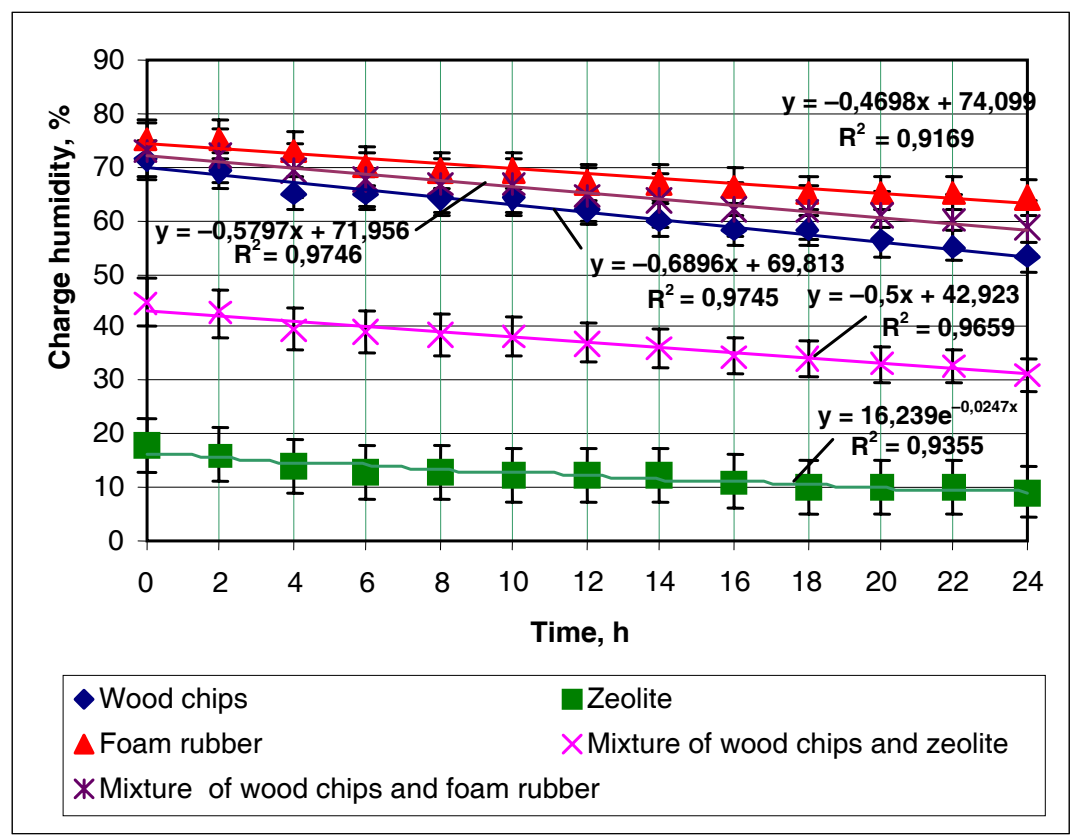

Fig 5. Dependence of the charge humidity on time

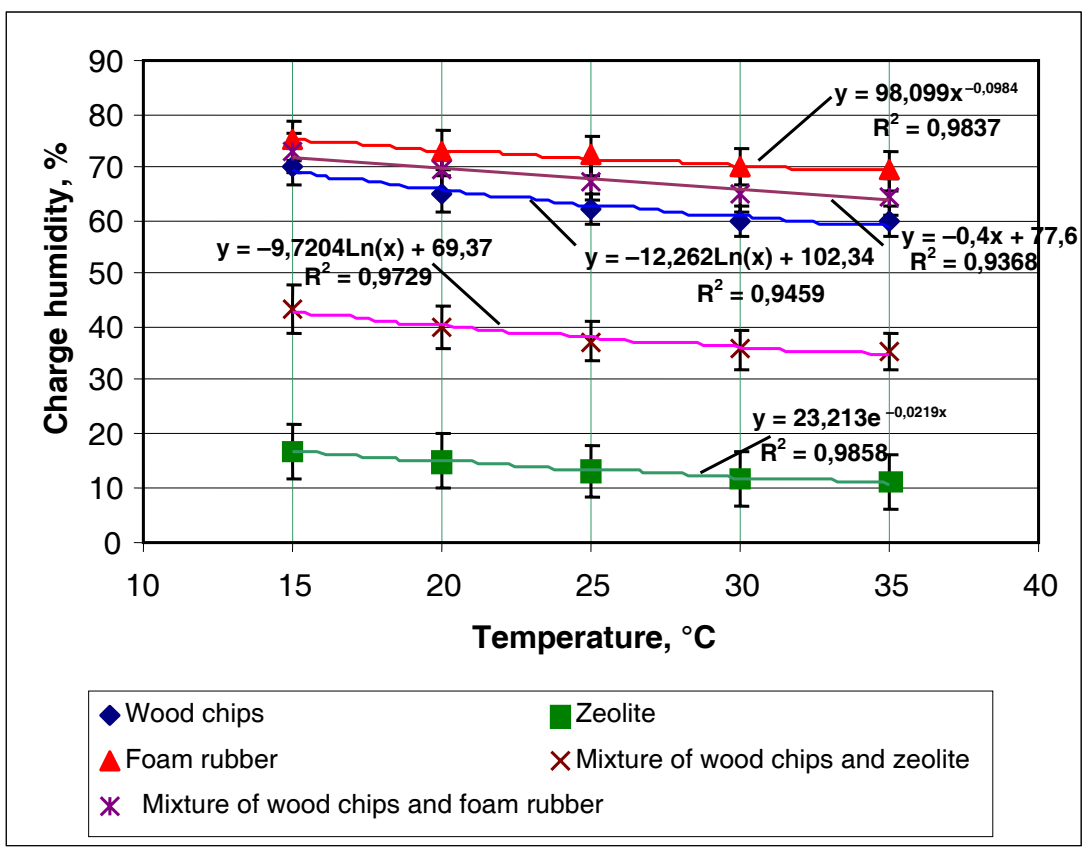

Fig 6. Dependence of the charge humidity on the supplied airflow temperature 
When airflow is supplied through the charge at the rate of $0.2 \mathrm{~m} / \mathrm{sec}$, after 5 hours the charge humidity decreases insignificantly at the temperature of $15^{\circ} \mathrm{C}$. Bigger temperature differences are noticed when the air temperature, and at the same time the biomedium temperature, is gradually increased. Upon increasing the temperature in the biofilter to $35^{\circ} \mathrm{C}$, the biggest humidity decrease was recorded in wood where humidity decreased from 70 to $60 \%$. The least susceptible to temperature changes is foam, whose humidity after 5 hours at the temperature of $35^{\circ} \mathrm{C}$ decreased to $68 \%$.

The results of investigation into humidity were influenced by microorganisms originating in the charge during humidification which absorbed carbon from wood and evolved a part of humidity.

To improve the cleaning efficiency of the equipment and maintenance of the charge humidity in the filter, the recommendation is to use the mixture of several different charges. In this way the useful life of the charge will be extended and input to maintain the charge humidity will be reduced. Zeolite has the highest resistance to temperature fluctuations, while foam - the lowest one.

Seeking to minimize the input of water used to humidify a charge, the mixture of wood and foam is recommended. Then, when maintaining the temperature most advantageous for microorganisms, $30{ }^{\circ} \mathrm{C}$, in the filter, the charge humidity after 5 hours would reach $65 \%$. Upon mixing wood chips with zeolite and maintaining the temperature of $30^{\circ} \mathrm{C}$ in the filter, the charge humidity would reach $36 \%$.

Upon reducing the zeolite fraction to $3 \mathrm{~mm}$, the humidity retention properties of this charge, and at the same time the energy of microorganisms in the biomedium, could be still more reinforced. Taking into consideration the fact that mesophilic microorganisms decompose volatile organic compounds best, the temperature in the biofilter would be in the range of $25-35^{\circ} \mathrm{C}$.

\section{Conclusions}

1. Microorganisms can reproduce only in such substrata which contain a certain amount of water and dissolved nutritious substances; therefore, charges were selected taking into account their good sorption properties and a large surface area. To improve the operation of charges, mixing of the charges is recommended.

2. As the experiments show, the best sorption properties were characteristic of foam, whose humidity reached around $70 \%$, and this was predetermined by a high porosity of the charge.

3. Zeolite has the weakest sorption properties. After pouring 11 of water on the charge, its humidity reached $18 \%$. A low humidity degree was predetermined by a low porosity of the charge. To improve it, the charge's fraction has to be reduced from $10-12 \mathrm{~mm}$ to $3-$ $5 \mathrm{~mm}$.

4. The mixture of zeolite and wood chips increases oxygen content in the charge and at the same time heightens the air-cleaning efficiency. Depending on different supplied airflow rates, the humidity of the charges varies in the range of $39-46 \%$.
5. With respect to time, a rather even decrease of humidity was recorded in the charge consisting of wood chips and foam. Both wood and foam, consisting of polymeric substances, have good water sorption properties. Humidity in this charge changed from 73 to $59 \%$ in 24 hours.

6. To improve the degradation of organic compounds, the use of several different charges of an organic and inorganic origin is recommended. In this way, the useful life and sorption properties of the charge, and at the same time biofilter's cleaning efficiency, will be increased.

\section{Acknowledgements}

The investigation was carried out under the project "Research and Development to Design a Biofilter Prototype".

The project is supported by the Republic of Lithuania and co-financed by the European Union.

\section{References}

1. LUTTIGHUIS, O. H. Möglichkeiten für Biofiltration in der pharmazeutischen Industrie. Tagungsbericht der VDIKommission Reinhaltung der Luft. Biologische Abgasreinigung. In Praktische Erfahrungen und neue Entwicklungen. VDI-Verlag, 1989, S. 341-349.

2. ZIGMONTIENE், A.; BALTRE்NAS, P. Biological purification of air polluted with volatile organic compounds by using active sludge recirculation. Journal of Environmental Engineering and Landscape Management, 2004, Vol XII, No. 2, p 45-52.

3. KLEINHEINZ, G. T.; BAGLEY, S. T. Biofiltration for the removal and detoxification of a complex mixture of volatile organic compounds. Journal of Industrial Microbiology \& Biotechnology, 1998, Vol. 20, p 101-108.

4. KOH, L. H.; DAVID, C. S.; KUHN, M.; MOHSENI, D.; GRANT, A. Pre-treatment of volatile organic compounds upstream of biological gas-cleaning operation. Journal of Chemical Technology and Biotechnology, 2004, Vol. 79, p 619-625.

5. CRUZ, A.; BUITRÓN, G. Biotransformation of disperse blue 79 by anaerobic sequencing batch biofilter. Water Science and Technology, 2000, Vol. 42, No. 5-6, p $317-$ 320.

6. PAUL, P. G.; KAUFMANN, R. Entfernung von Schwefelverbindungen in Kompaktbiofilteranlagen. Tagungsbericht der VDI-Kommission Reinhaltung der Luft. Biologische Abgasreinigung. In Praktische Erfahrungen und neue Entwicklungen. VDI-Verlag, 1989, S. 331-341.

7. JANKEVIČIUS, K.; LIUŽINAS, R. Aplinkos biologinis valymas: monografija. Vilnius: Apyaušris, 2003. 106 p.

8. LUGAUSKAS, A.; BRIDŽIUVIENĖ, D.; LEVINSKAITĖ, L. Mikrobiologiniai medžiagu pažeidimai. Vilnius, 1997. $467 \mathrm{p}$.

9. BALTRĖNAS, P.; ZIGMONTIENĖ, A.; VAIŠKŪNAITÉ, R. Oro valymo biotechnologijos: monografija. Vilnius: Technika, 2004.

10. BALTRĖNAS, P.; PALIULIS, D. Adsorbciniai oro valymo filtrai: monografija. Vilnius: Technika, 2002.

11. BALTRĖNAS, P.; VAIŠKŪNAITĖ, R.; ZAGORSKIS, A. Experimental studies of airflow rate and aerodynamic resistance of biological air-purification device that contains 
activated fir-bark charge. In The $6^{\text {th }}$ International Conference Proceedings an Environmental Engineering held on 26-27 May 2005. Vilnius: Technika, 2005, p 25-29.
12. BALTRĖNAS, P.; VAIŠKŪNAITĖ, R. Biologinis oro valymas suaktyvinta žievių ikkrova. Aplinkos inžinerija (Environmental Engineering), 2002, X t., Nr. 2, p 70-76.

\section{BIOLOGINIAM ORO VALYMUI NAUDOJAMOS İKROVOS DRE்GNUMO NUSTATYMO TYRIMAI \\ P. Baltrènas, A. Zagorskis \\ Santrauka}

Mikroorganizmai gali daugintis tik tokiuose substratuose, kuriuose yra tam tikras kiekis vandens ir ištirpusių maisto medžiagų. Todèl būtina ieškoti tokių ikrovų, kurios pasižymètų dideliu filtravimo paviršiaus plotu bei geromis drègmės sulaikymo savybėmis. Eksperimentiniams tyrimams panaudota trijų rūšių ikkrova, sudaryta iš medienos drožlių, ceolito ir porolono gabaliukų. Siekiant kuo ilgiau biofiltre išlaikyti mikroorganizmams reikiamą drègmę, ikrovos buvo maišomos. Jos įdedamos į skirtingas kasetes, ịrengtas biofiltre. Medienos ịkrovą sudarè 10-15 mm frakcijos medienos drožlès, ceolitą - 10-12 mm frakcijos iš ceolito sudaryti grūdeliai. Porolonas supjaustytas į kubelius, kurių kiekvieno matmenys: $30 \times 30 \times 20 \mathrm{~mm}$. Buvo nustatyta ịkrovų drègnumo priklausomybė nuo oro srauto greičio, temperatūros ir įkrovos sluoksnio storio. Oro srauto greitis siekė $0,1-0,5 \mathrm{~m} / \mathrm{s}$, o temperatūros intervalas $-15-35{ }^{\circ} \mathrm{C}$. Geriausiomis sorbcinèmis savybèmis pasižymejjo porolonas, tačiau geresnis drègmès pasiskirstymas nustatytas medienos skiedrų įkrovoje.

Reikšminiai žodžiai: biofiltras, lakieji organiniai junginiai, biodegradacija, ceolitas, adsorbcija, mikroorganizmai.

\section{ИССЛЕДОВАНИЕ ВЛАЖНОСТИ ЗАГРУЗКИ В БИОЛОГИЧЕСКОМ ПРОЦЕССЕ ОЧИСТКИ ВОЗДУХА}

\section{П. Балтренас, А. Загорскис}

Резюме

Микроорганизмы могут размножаться лишь в субстратах, в которых имеется вода и минеральные вещества. Поэтому необходимы сорбенты, отличающиеся большой фильтрующей поверхностью и хорошей сорбцией влажности. В экспериментах исследовались три типа материалов, включая древесину, цеолит и поролон, которые использовались в качестве загрузки для биологического процесса очистки воздуха. Загрузка помещалась в кассеты биофильтра. Фракция древесины составляла 10 мм, цеолита - 15 мм. Поролон разрезался на куски размером $30 \times 30 \times 20$ мм. В результате были найдены зависимости влажности загрузки от скорости потока подаваемого воздуха, его температуры и толщины слоя загрузки. Во время экспериментов скорость потока подаваемого воздуха составляла $0,1-0,5 \mathrm{~m} / \mathrm{c}$, а температура $-15-35^{\circ} \mathrm{C}$. Воду лучше сорбировал поролон, однако лучшее распределение влажности зафиксировано в древесной загрузке.

Ключевые слова: биофильтр, летучие органические соединения, биологический распад, цеолит, адсорбция, микроорганизмы.

Pranas BALTRÉNAS. Dr Habil, Prof and head of Dept of Environmental Protection, Vilnius Gediminas Technical University (VGTU).

Doctor Habil of Science (air pollution), Leningrad Civil Engineering Institute (Russia), 1989. Doctor of Science (air pollution), Ivanov Textile Institute (Russia), 1975. Employment: Professor (1990), Associate Professor (1985), senior lecturer (1975), Vilnius Civil Engineering Institute (VISI, now VGTU). Publications: author of 13 monographs, 24 study-guides, over 320 research papers and 67 inventions. Honorary awards and membership: prize-winner of the Republic of Lithuania (1994), a corresponding Member of the Ukrainian Academy of Technological Cybernetics, a full Member of International Academy of Ecological and Life Protection Sciences. Probation in Germany and Finland. Research interests: air pollution, pollutant properties, pollution control equipment and methods.

Alvydas ZAGORSKIS. Master, doctoral student (since 2005), Dept of Environmental Protection, Vilnius Gediminas Technical University (VGTU).

Bachelor of Science (environmental engineering), VGTU, 2003. Publications: author/co-author of 12 research papers. Research interests: environmental protection, pollution prevention, biotechnology of air purification. 